\title{
The Effect of Capital Adequacy Ratio, Financing to Deposit Ratio, Non Performing Financing, Operating Expenses, Operating Income and Good Corporate Governance towards the Profitability of Islamic Banking Listed in Bank of Indonesia
}

\author{
Arfan Ikhsan', Muamar Khadafi ${ }^{2}$, Muhammad Yamin Noch ${ }^{3}$, Aristia Paramitha ${ }^{1}$, Wahyudin \\ Albra $^{2}$ \\ \{arf_79lbs@yahoo.com,khaddafi@unimal.ac.id, abienoch12@gmail.com, paramithaaristia@gmail.com, \\ wahyuddin@unimal.ac.id\} \\ ${ }^{1}$ State University of Medan, Indonesia \\ ${ }^{2}$ University of Malikusaleh, Indonesia \\ ${ }^{3}$ University of Yapis Papua, Indonesia
}

\begin{abstract}
This study aims to examine the effect of Capital Adequacy Ratio (CAR), Financing to Deposite Ratio (FDR), Non Performing Ratio (NPF), Operating Expenses and Operating Income (BOPO), and Good Corporate Governance (GCG) towards the profitability of Islamic Banking listed in Bank of Indonesia for the period 2011-2015. The population of this study is all listed Islamic Bankings in Bank of Indonesia. The samples are the Islamic Banks that have been established for 5 years and have published audited financial statements and have implemented good corporate governance system during the study period. The data analysis in this research used quantitative approach with classical assumption test, multiple regression analysis and hypothesis test assisted by SPSS 20. The results shows that the regression model is independent of multicolinearity, heteroscedasticity, autocorrelation symptoms, and the data results are normally distributed. Multiple regression analysis shows that Capital Adequacy Ratio (CAR) has positive and significant effect on profitability, Financing to Deposite Ratio (FDR) and Non Performing Adequacy Ratio (NPF) have significant and negative effect on profitability, Operating Expenses and Operating Income (BOPO) and Good Corporate Governance (GCG) has no effect on profitabiity.
\end{abstract}

Keywords: Capital Adequacy Ratio, Financing to Deposit Ratio, Non Performing Financing, Operating Expenses, Operating Income, Good Corporate Governance, Profitability

\section{Introduction}

Banking is one of the supports that strengthen the economic system of a country, because bank serves as a financial intermediary that acts as an institution that can collect and channel funds to the community effectively and efficiently. With the increase in the number of banks, competition to raise funds from the community increases which will be channeled back for those who need both for productive and consumptive purposes. For banks, funds are the most important matter and without funds banks will not run properly. 
The monetary crisis in 1998 that happened in Indonesia had a significant impact on Indonesian economy, especially on banking structure. This led to declining public confidence in national banking system. The development of Islamic banking that began to develop in Indonesia attracts people attention to raise their funds in banks. Therefore, Islamic banks should improve their existence and condition in order not liquidated by Bank of Indonesia.

Islamic bank is an operating bank that is not based on interest system. Islamic bank is a financial institution/banking in which its operation and products are developed based on AlQuran and Hadith (Damastuti, 2010). The purpose of Islamic banking is to support the implementation of national development and real sector through Islamic-based finance for the welfare of the people. The development of Islamic banking can be seen from the statistics table of Islamic banking per June 2015. Currently, there are 12 Islamic Commercial Banks with 2,121 offices, 22 Islamic Business Unit with 327 offices and 161 Islamic Rural Banks with 433 offices (Bank of Indonesia, 2015).

Islamic banking as a financial intermediary institution is expected to show better performance than banks based on interest system. One indicator to assess company performance is by looking at the profitability level. Profitability of banking company can be reviewed by comparing the items contained in the financial statements.

The factors affecting the profitability of banks include capital, liquidity, asset quality, operational efficiency and corporate governance. The important profitability ratio for banks is Return on Assets (ROA) because it is used to measure the effectiveness of company in generating profits by exploiting its assets. There are measuring tools that can be used as a gauge of the factors that affect profitability i.e. Return On Assets (ROA), Capital Adequacy Ratio (CAR), Financing to Deposit Ratio (FDR), Non Performing Financing (NPF), Operating Expenses and Operating Income (BOPO) and Good Corporate Governance (GCG). The development of average financial ratios on Islamic banking in Indonesia in 2011-2015 can be seen in Table 1 as follows:

Table 1. The Development Of Islamic Banking Financial Ratio (In percentage)

\begin{tabular}{llccccc}
\hline $\mathbf{N}$ & & $\mathbf{2 0 1}$ & $\mathbf{2 0 1}$ & $\mathbf{2 0 1}$ & $\mathbf{2 0 1}$ & $\mathbf{2 0 1}$ \\
$\mathbf{0}$ & Indicators & $\mathbf{1}$ & $\mathbf{2}$ & $\mathbf{3}$ & $\mathbf{4}$ & $\mathbf{5}$ \\
\hline 1 & Capital Adequacy Ratio (CAR) & 16.6 & 14.1 & 14.2 & 15.7 & 14.1 \\
\hline 2 & Return On Assets (ROA) & 1.8 & 2.1 & 2 & 0.8 & 2.2 \\
\hline 3 & $\begin{array}{l}\text { Operating Expenses and Operating } \\
\text { Income (BOPO) }\end{array}$ & 78.4 & 75 & 78 & 94.1 & 94.2 \\
\hline 4 & Financing to Deposit Ratio (FDR) & 88.9 & 100 & 102. & 91.5 & 96.5 \\
\hline 5 & Non Performing Financing (NPF) & & & 8 & & \\
\hline \multicolumn{7}{r}{ Source: Data taken from www.ojk.go.id } \\
\end{tabular}

In Table 1, the indicators of Return on Assets (ROA), Capital Adequacy Ratio (CAR), Financing to Deposit Ratio (FDR), Non Performing Financing (NPF) and Operating Expenses and Operating Income (BOPO) of Islamic banks fluctuated. Capital Adequacy Ratio (CAR) experienced a sharp decline in 2012 by 14.1 percent and also declined in 2015 by 14.1 percent compared to 2014 by 15.7 percent. Capital Adequacy Ratio (CAR) shows the bank ability to maintain sufficient capital and the bank management ability to identify, measure, monitor and control risks that can affect the amount of capital. Return on Assets (ROA) indicates 0.8 
percent in 2014 where the Return On Asset (ROA) has declined from the previous year and experienced a sharp increase in 2015 by 2.2 percent

The reason for choosing Return On Asset (ROA) as a measure of performance is due to return on assets (ROA) can be used to measure the ability of bank management to gain overall profit. The higher Return on Assets (ROA) of a bank, the greater the level of profit the bank achieves and the better the bank position in terms of the use of assets (Wibowo \& Syaichu, 2013). Operational Expenses and Operating Income (BOPO) decreased in 2012 by 75 percent and faced a very sharp increase from the previous year in 2014 by 94.1 percent and decreased in 2015 by 94.2 percent. This indicates that Islamic banking can control its operations. Operational Expenses and Operating Income (BOPO) is used to measure the level of efficiency and ability of banks in conducting operations. The smaller this ratio then the Return On Asset (ROA) increases (Rahmi \& Anggraini, 2013). In 2011-2013, Financing to Deposit Ratio (FDR) experienced an increase by 102.8 percent in 2013, and then in 2014 Financing to Deposit Ratio (FDR) decreased by 91.5 percent and increased further in 2015 by 96.5 percent due to the economic downturn. Financing to Deposit Ratio (FDR) is used to measure the level of bank liquidity that demonstrates the ability of banks to meet the credit demand by using the total assets owned by a bank.

Non Performing Financing (NPF) experienced a sharp rise from the previous year in 2014 by 4.3 percent. This means that there were bad credits in 2014. Non Performing Financing (NPF) is used to measure the level of financing issues faced by Islamic banks. In the five-year period in 2009-2013, the average growth of Islamic bank assets was 43 percent and currently the growth has dropped dramatically. The decline in the growth of Islamic banking is not only in terms of assets, but also financing and third party funds (DPK). This is due to the increase in deposit interest rates in conventional banks so that some customers of Islamic banks transferred their funds to conventional commercial banks. The slowing growth is exacerbated by the increasing ratio of Non Performing Financing (NPF) because of the influence of the write-off made by the banks and the sale of assets of some banks and this led to a decline in customers of financing.

One cause of the decline in the growth of Islamic bank assets that affect profitability is small capital (BeritaSatu, 2015). Capital capability is assumed to be one of the reasons for the slow expansion of Islamic banking office network. Especially after the implementation of the regulation concerning the opening of Islamic Commercial Bank Office and Islamic Business Unit which is linked to Islamic bank core capital. Although it has no impact on all Islamic banks, this rule limits the motion of some banks with limited capital conditions. This condition is reflected in the Capital Adequacy Ratio (CAR) of Islamic banking which until April 2014 it was recorded at 16.68 percent or lowers than the Capital Adequacy Ratio (CAR) of national banks that reached 19.35 percent. Then the growth of Islamic banking since the end of 2014 until the first half of 2015 was considered relatively stagnant in terms of asset. Judging by the condition of Islamic banking until the first half of 2015 in the Islamic banking business indicators, there was a decrease in the Capital Adequacy Ratio (CAR), Financing to Deposit Ratio (FDR) and Non-Performing Financing (NPF). Although on the other hand, there were a number of indicators that show improvement like return on assets (ROA) and BOPO.

In addition to financial ratios, there are other factors affecting the profitability of Islamic banking i.e. good corporate governance. Corporate governance is the structure and mechanism governing the management of a company so as to produce long-term economic value that is sustainable for shareholders and stakeholders. The application of good corporate governance principles can contribute in improving the performance of company. Therefore, every bank needs to do good corporate governance in accordance with the provisions of Bank of 
Indonesia, especially banking companies whose funds are largely from the people. Good corporate governance is necessary to attract public trust.

This study aims to identify and describe the influence of Capital Adequacy Ratio (CAR), Financing to Deposit Ratio (FDR), Non Performing Financing (NPF), Operating Expenses and Operating Income (BOPO), and Good Corporate Governance on profitability of Islamic Banking. This study differs from previous studies in terms of a longer duration of sampling between 2011-2015. The longer period is intended to get more data and the results of this research have better comparability.

\section{Literature Review}

\subsection{Islamic Bank}

The meaning of Islamic banks or sharia banks is banks that operate with no reliance on interest. Islamic banking is a banking institution that is consistent with Islamic value and ethos system. In other words, Islamic banks are financial institutions/banking whose operational and products are developed based on Islamic Sharia (Al-Qur'an and Hadith of the Prophet) and use fiqh rules and its main business is to provide financing and other services, or circulation of money in which its implementation is adapted to the principle of Islam (Iska, 2012).

According to Law No. 10 Year 1998, Islamic Commercial Bank is a bank that conducts its business activities based on islamic principles in which its activity provides payment traffic services. Islamic principle is a rule of agreement based on Islamic law between banks and other parties for the storage of funds and financing of business activities. Thus, in conducting its operational activities, Islamic banks do not only apply sharia-compliant finance but also collect fund from people in accordance with Islamic sharia.

The financial statements in Islamic banking sector is the same as the other sectors to provide information relating to financial position, performance, and changes in financial position of bank operations that are useful in making decisions. The financial statements produced by bank are expected to provide information on financial performance and accountability of bank management to all bank stakeholders.

\subsection{Profitability Ratio}

According to (Kieso, Weygandt, \& Warfield, 2008), profitability ratio is the ratio used to measure the effectiveness of the overall management of company as shown by the amount of profits obtained by the company. Profitability is a measure in percentage that is used to assess the extent to which a company is able to generate profits at acceptable levels. Profitability generated by Islamic banks not only affects share-sharing rates for shareholders, but also affects profit-sharing rate received by depositors. Therefore, Islamic banks must continue to improve profitability. Return on Assets (ROA) is a ratio used to measure the ability of bank management in gaining total profit (Pratiwi, 2012). According to (Alifah, 2014), Return on Assets (ROA) is the ratio between profits before tax and the average total assets during certain period.

\subsection{Capital Adequacy Ratio}

Capital Adequacy Ratio (CAR) is a ratio showing how much of the total assets of a bank that contains an element of risk (credit, investments, securities, bills to other banks) that are financed from its own capital in addition to obtaining funds from sources outside the 
bank (Yuliani, 2007). Meanwhile, according to Mudrajad and Suhardjono (2002) in (Adyani, 2011), Capital Adequacy Ratio (CAR) indicates the bank ability to maintain sufficient capital and the management ability to identify, measure, monitor and control risks that can affect the amount of capital. Under the provisions of Bank for International Settlements, healthy banks are required to have Capital Adequacy Ratio (CAR) of at least $8 \%$ capital against assets, if less than the provisions, it will be sanctioned by the central bank (Janah \& Siregar, 2018).

\subsection{Financing to Deposit Ratio (FDR)}

Capital Adequacy Ratio (CAR) is a ratio showing how much of the total assets of a bank that contains an element of risk (credit, investments, securities, bills to other banks) that are financed from its own capital in addition to obtaining funds from sources outside the bank (Yuliani, 2007)). Meanwhile, according to Mudrajad and Suhardjono (2002) in (Adyani, 2011), Capital Adequacy Ratio (CAR) indicates the bank ability to maintain sufficient capital and the management ability to identify, measure, monitor and control risks that can affect the amount of capital. Under the provisions of Bank for International Settlements, healthy banks are required to have Capital Adequacy Ratio (CAR) of at least $8 \%$ capital against assets, if less than the provisions, it will be sanctioned by the central bank (Janah \& Siregar, 2018).

\subsection{Non Performing Financing (NPF)}

Non Performing Financing (NPF) that is analogous to non-performing loans (NPL) in conventional bank is a financial ratio that reflects credit risk. Non Performing Financing (NPF) is a ratio between non-performing financing and total financing distributed by Islamic banks (Pratiwi, 2012). Non Performing Financing (NPF) is used to measure the level of financing issues faced by Islamic banks. In order for bank performance to increase, each bank must keep Non Performing Financing (NPF) below 5\%; this is in line with the provisions of Bank of Indonesia.

\subsection{Operating Expences and Operating Income (BOPO)}

According to (Alifah, 2014), Operating expenses and Operating Income (BOPO) is a ratio between the costs incurred by the bank in carrying out its main activities and the revenue derived from the activities. Operational expense ratio is used to measure the level of efficiency and ability of banks in conducting operations. The efficiency level of banks in running its operations affects the level of income generated by the bank. If the operational activities are carried out efficiently then the income generated by the bank will rise, the lower the Operating Expenses and Operating Income (BOPO), the more efficient the bank in controlling its operating costs. The cost efficiency of banks will make even greater profits.

\subsection{Good Corporate Governance}

Good Corporate Governance (GCG) is one of the factors of rating the bank. The concept of Good Corporate Governance (GCG) is proposed in order to achieve a more transparent corporate management for all users of financial statements (Lieu, 2015). Thus, Good Corporate Governance (GCG) encourages the creation of fair competition and encouraging business climate to support sustainable growth and economic stability. Islamic Bank as a business entity committed to carrying out all business transactions in accordance 
with Islamic values should be able to apply this overall accountability. In addition, Islamic Bank as an entity should promote openness, honesty, fairness and fairness.

\section{Methodology}

\section{1 Relationship between adenquency ratio and return on asset}

According to Mawardi in (Fitriyana, 2011), the high Capital Adequacy Ratio (CAR) can be caused by capital injection from the owners in the form of fresh money to anticipate the development of business scale in the form of credit expansion. The high ratio of capital can protect depositors and impact the increase in public confidence and ultimately the increase in Return On Asset (ROA). The greater the Capital Adequacy Ratio (CAR), the greater bank profits. This is supported by research results by Prasitiningtyas (2010), (Adyani, 2011; Fahmy, 2014; Rahmi \& Anggraini, 2013; Wibowo \& Syaichu, 2013; Zulifiah \& Susilowibowo, 2014) that Capital Adequacy Ratio (CAR) has positive insignificant effect on profitability (ROA) of bank. From the explanation, the first hypothesis is as follows:

H1: Capital Adequacy Ratio (CAR) has positive effect on Return on Assets (ROA)

\section{2 Relationship between Financing to Deposit Ratio and Return On Asset}

The relationship between Financing to Deposit Ratio (FDR) on Return On Assets (ROA) is negative because if bank wants to maintain its liquidity position by increasing cash reserves, the bank cannot use the whole loanable funds because some will be refunded in cash reserves so that it will reduce the effort to achieve profitability. Conversely, if a bank wants to enhance profitability, then the existing cash reserve for liquidity is used for bank business, so the liquidity position will be going down (Danupranata, 2013). This is supported by the research results by, (Hakiim \& Rafsanjani, 2016; Muiawati, 2015) that state that Financing to Deposit Ratio (FDR) negatively affect return on assets (ROA). From the explanation, the second hypothesis is as follows:

H2: Financing to Deposit Ratio (FDR) has negative effect on Return On Asset (ROA)

The population of this research is Islamic commercial banks listed in Bank of Indonesia (BI) in 2011-2015. The method used in determining sampling is by using purposive sampling method, which means that the companies as samples of this study were selected by using some consideration by including certain elements that have certain criteria. Some of the criteria for the selection of sample to be examined in this study are as follows: 1) Islamic Banks that have been established for 5 years and have published audited financial report, 2) Islamic Banks that have implemented the system of Good Corporate Governance, and 3) Islamic Banks that have been publishing report of good corporate governance in the annual financial statements during the study period. The following is a list of Islamic commercial banks listed in Bank of Indonesia.

Table 2. List of Islamic Commercial Banks

\begin{tabular}{llc} 
No. & \multicolumn{1}{c}{ Bank name } & Since \\
\hline 1 & Bank of Muamalat & 1992 \\
\hline 2 & Bank of Syariah Mandiri & 1999 \\
\hline 3 & Bank of Mega Syariah & 2004 \\
\hline
\end{tabular}




\begin{tabular}{lll}
\hline 4 & BRI Syariah & 2008 \\
\hline 5 & Panin Bank Syariah & 2009 \\
\hline 6 & Bank Syariah Bukopin & 2009 \\
\hline 7 & Bank of Victoria Syariah & 2010 \\
\hline 8 & BCA Syariah & 2010 \\
\hline 9 & $\begin{array}{l}\text { Bank Jabar and Banten } \\
\text { Syariah }\end{array}$ & 2010 \\
\hline 10 & BNI Syariah & 2010 \\
\hline 11 & Maybank Syariah & 2010 \\
\hline 12 & BTPN Syariah & 2014 \\
\hline
\end{tabular}

Source: www.bi.go.id

Based on the above sample selection criteria, the sampling can be viewed through the list of banks in Table 2 in order to obtain the total sample of 7 Islamic Banks, it is shown in Table 3.

Table 3. Research Samples

\begin{tabular}{llc} 
No. & Bank name & Since \\
\hline 1 & Bank of Muamalat & 1992 \\
\hline 2 & $\begin{array}{l}\text { Bank of Syariah } \\
\text { Mandiri }\end{array}$ & 1999 \\
\hline 3 & Bank of Mega Syariah & 2004 \\
\hline 4 & BRI Syariah & 2008 \\
\hline 5 & Panin Bank Syariah & 2009 \\
\hline 6 & Bank Syariah Bukopin & 2009 \\
\hline 7 & Bank Victoria Syariah & 2010 \\
\hline
\end{tabular}

To avoid disruption in research data, first, classical assumption test was performed consisting of multicoloniarity, heteroscedasticity and autocorrelation test. To ensure the resulting data is normally distributed then the normality of the data was tested. Of the entire tests, it is considered that this research is free from classical assumption test and the research data are also normally distributed as shown in Figure 1 below.

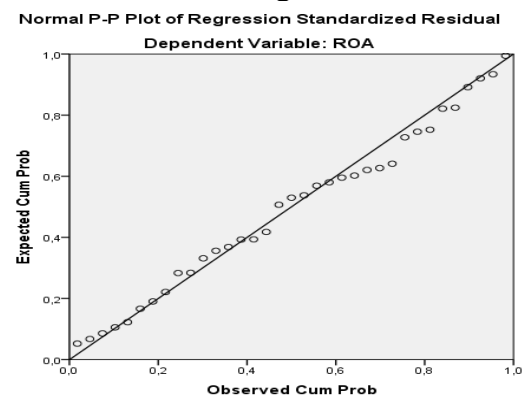

Fig. 1. Normality Test With Normal PP Plot Source: SPSS output, 2017.

To test the hypothesis of the research, multiple linear regression model was conducted with the statistical equation as follows: 
Where:

$$
\mathrm{Y}=\alpha+\mathrm{b} 1 \mathrm{X} 1+\mathrm{b} 2 \mathrm{X} 2+\mathrm{b} 3 \mathrm{X} 3+\mathrm{b} 4 \mathrm{X} 4+\mathrm{b} 5 \mathrm{X} 5+
$$

$\mathrm{Y} \quad=$ ROA (Return on Assets)

A $=$ Constant (the value of $\mathrm{Y}$ if $\mathrm{X}_{1} \mathrm{X}_{2} \mathrm{X}_{3} \mathrm{X}_{4} \mathrm{X}_{5}=0$ )

$\mathrm{X}_{1} \quad=$ Capital Adequacy Ratio (CAR)

$\mathrm{X}_{2} \quad=$ Financing to Deposit Ratio (FDR)

$\mathrm{X}_{3} \quad=$ Non Performing Financing (NPF)

$\mathrm{X}_{4}=$ Operational Expenses and Operating Income (BOPO)

$\mathrm{X}_{5} \quad=$ Good Corporate Governance (GCG)

$\mathrm{b}_{1, \ldots} \mathrm{b}_{5}=$ Regression Coefficients (increase or decrease value)

$\mathrm{E} \quad=$ Nuisance variable (Error term)

\section{Findings And Discussion}

\subsection{Descriptive Statistics}

Based on the calculations in Table 4, it shows that the number of observations in the Islamic Banks in this study was 35 observations of banking company from 7 samples of Islamic banks in the period of 2011 to 2015 . Based on the results of descriptive statistical analysis in the table, it can be seen that: Return on Assets (ROA) has a statistically obtained value of 1.1397 with a standard deviation of 1.55744 . The minimum value of Return on Assets (ROA) of -2.36 and maximum value of 6.93, Capital Adequacy Ratio (CAR) has minimum value of 11.10 and maximum value of 61.98. Capital Adequacy Ratio (CAR) has average value of 18.1397 greater than the standard deviation of 10.23341 . Non Performing Financing (NPF) has an average value of 3.5614 and standard deviation value of 2,11324. The minimum value of Non Performing Financing (NPF) is 0.20 and maximum value is 9.80. Financing to Deposite Ratio (FDR) during the period of 2011-2015 had an average value of 92.1671 and a standard deviation of 16,65184. The minimum value of Financing to Deposite Ratio (FDR) is 46.08 and maximum value is 167.70. Operating Expenses to Operating Income (BOPO) has an average value of 113.5651 with a standard deviation of 139.23202. The minimum value of Operating Ratio to Operating Income (BOPO) is 47.60 and the maximum value is 908.00. Good Corporate Governance (GCG) in the year of 2011-2015 had an average value of 1.7334 with a standard deviation of 0,35780 . The minimum value of Good Corporate Governance (GCG) is 1.35 and maximum value is 3.00.

Table 4. Result of Descriptive Analysis at Islamic Commercial Bank

\begin{tabular}{lrrrrr}
\hline \multicolumn{6}{c}{ Descriptive Statistics } \\
\hline N & Min & Max & Mean & $\begin{array}{c}\text { Std. } \\
\text { Deviatio } \\
\text { n }\end{array}$ \\
\hline CAR & 3 & 11,1 & 61,98 & 18,1397 & 10,2334 \\
& 5 & 0 & & & 1 \\
\hline FDR & 3 & 46,0 & 167,7 & 92,1671 & 16,6518 \\
& 5 & 8 & 0 & & 4 \\
\hline NPF & 3 &, 20 & 9,80 & 3,5614 & 2,11324 \\
& 5 & & & & \\
\hline BOPO & 3 & 47,6 & 908,0 & 113,565 & 139,232 \\
\hline
\end{tabular}




\begin{tabular}{lrrrrr}
\hline & 5 & 0 & 0 & 1 & 02 \\
\hline ROA & 3 & - & 6,93 & 1,1397 & 1,55744 \\
& 5 & 2,36 & & & \\
\hline GCG & 3 & 1,35 & 3,00 & 1,7334 &, 35780 \\
& 5 & & & & \\
\hline Valid N & 3 & & & & \\
(listwise) & 5 & & & & \\
\hline
\end{tabular}

\subsection{Multiple Regression Analysis}

Based on table 6, the multiple regression model is obtained as follows: $\mathrm{Y}=5,629+$ $0,067 \mathrm{X}_{1}-0,045 \mathrm{X}_{2}-0,413 \mathrm{X}_{3}+4,672 \mathrm{X}_{4}-0,079 \mathrm{X}_{5}+\mathrm{e}$. The interpretation of the multiple regression equation is as follows: Constant value of 5.629 states that if all independent variables are considered constant or zero, then the value of dependent variable or profitability of islamic banks is 5.629. The regression coefficients value of Capital Adequacy Ratio (CAR) is positive for 0,067 showing that any increase in Capital Adequacy Ratio (CAR) of $1 \%$, the CAR will increase by 0,067 with the assumption that the other variables are constant or fixed. The regression coefficients value of Financing to Deposit Ratio (FDR) is negative at -0.045 indicating that any increase in Financing to Deposit Ratio (FDR) of 1\%, the FDR will decrease by 0,045 with the assumption that the other variables are constant or fixed. The regression coefficients value of Non Performing Financing (NPF) is negative at -0.413 indicating that any increase in Non Performing Financing (NPF) of 1\%, the Non-Performing Financing (NPF) will decrease by 0.413 assuming that the other variables are constant or fixed. The regression coefficients value of Operating Expenses and Operating Income (BOPO) is positive for 4.672 showing that every increase in Operating Expenses and Operating Income by $1 \%$, the BOPO will increase by 4.672 assuming that the other variables are constant or fixed. The regression coefficients value of Good Corporate Governance (GCG) is negative at 0.079 indicating that every increase in Good Corporate Governance (GCG) of $1 \%$, the GCG will decrease by 0.079 assuming that the other variables are constant or fixed.

Table 5. Multiple Regression Test Results

\begin{tabular}{|c|c|c|c|c|c|}
\hline \multirow{4}{*}{$\begin{array}{l}\text { Mode } \\
1\end{array}$} & \multicolumn{5}{|c|}{ Coefficients ${ }^{\mathrm{a}}$} \\
\hline & \multirow{2}{*}{\multicolumn{2}{|c|}{$\begin{array}{l}\text { Unstandardized } \\
\text { Coefficients }\end{array}$}} & Standardized & \multirow[t]{3}{*}{$\mathrm{t}$} & \multirow[t]{3}{*}{ Sig. } \\
\hline & & & Coefficients & & \\
\hline & B & Std.Error & Beta & & \\
\hline \multirow[t]{9}{*}{1} & (Consta & 5,629 & 1,276 & & 4,410 \\
\hline & nt) & & & & \\
\hline & CAR &, 067 & ,020 &, 440 & 3,345 \\
\hline & FDR &,- 045 & ,011 &,- 476 & - \\
\hline & & & & & 4,112 \\
\hline & NPF &,- 413 & ,122 &,- 560 & - \\
\hline & & & & & 3,387 \\
\hline & BOPO & 4,672E- & 001 & ,004 & ,038 \\
\hline & & 005 & & & \\
\hline
\end{tabular}




\begin{tabular}{|c|c|c|c|c|c|}
\hline \multicolumn{6}{|c|}{ Coefficients $^{\mathbf{a}}$} \\
\hline \multirow{4}{*}{$\begin{array}{l}\text { Mode } \\
1\end{array}$} & Unsta1 & lized & Standardized & $\mathrm{t}$ & Sig. \\
\hline & Coeffi & & Coefficients & & \\
\hline & $\mathrm{B}$ & Std.Error & Beta & & \\
\hline & GCG &,- 079 &, 665 &,- 018 &,- 118 \\
\hline
\end{tabular}

Source : SPSS Output, 2017

To know the influence of independent variables partially in explaining the variation of dependent variables, t-test and $\mathrm{F}$ statistical test were used to determine whether all independent variables simultaneously influence dependent variable at the significant level of $0.05(5 \%)$ as shown in Table 7 . Based on t test results, the direction of the regression beta coefficient and its significance with t table is $1.69092(\mathrm{df}=35-1=34)$ at 0.05 .

Table 6. $t$ Test Results (Partial Test)

\begin{tabular}{ccccc}
\hline $\begin{array}{c}\text { Hypothe } \\
\text { sis }\end{array}$ & $\begin{array}{c}\text { Independe } \\
\text { nt }\end{array}$ & $\begin{array}{c}\text { t } \\
\text { count }\end{array}$ & Sig. & Note \\
\hline H1 & CAR & 3,345 & 0,002 & $\begin{array}{c}\text { Accepte } \\
\text { d }\end{array}$ \\
\hline H2 & FDR & - & 0,000 & $\begin{array}{c}\text { Accepte } \\
\text { d }\end{array}$ \\
\hline H3 & NPF & - & 0,02 & $\begin{array}{c}\text { Accepte } \\
\text { d }\end{array}$ \\
\hline H4 & BOPO & 0,038 & 0,970 & $\begin{array}{c}\text { Rejecte } \\
\text { d }\end{array}$ \\
\hline H5 & GCG & $-0,18$ & 0,907 & $\begin{array}{c}\text { Rejecte } \\
\text { d }\end{array}$ \\
\hline
\end{tabular}

While the results of $F$ test calculation as shown in Table 8 , the calculated $F$ value is $11.855>$ F table of 2.49 to 0.000 significantly smaller than 0.05 . Thus, it can be concluded that the Capital Adequacy Ratio (CAR), Financing to Deposit Ratio (FDR), Non Performing Financing (NPF), Operating Expenses and Operating Income (BOPO), and Good Corporate Governance (GCG) simultaneously affect Return On Asset (ROA) in Islamic commercial banks.

Table 7. F Test Results (Simultaneous Test)

\begin{tabular}{llrrrrr}
\hline \multirow{2}{*}{ Model } & $\begin{array}{l}\text { Sum of } \\
\text { Squares }\end{array}$ & Df & $\begin{array}{c}\text { Mean } \\
\text { Square }\end{array}$ & F & Sig. \\
\hline 1 & $\begin{array}{l}\text { Regressio } \\
\mathrm{n}\end{array}$ & 55,378 & 5 & 11,076 & 11,855 & $\begin{array}{c}\text {,000 } \\
\mathrm{b}\end{array}$ \\
\cline { 2 - 6 } & & 27,093 & 29 &, 934 & & \\
\hline & 82,471 & 34 & & & \\
\hline
\end{tabular}

a. Dependent Variable: ROA

b. Predictors: (Constant), GCG, CAR, BOPO, FDR, NPF 
Meanwhile, based on the testing results of coefficient of determination $\left(\mathrm{R}^{2}\right)$ in Table 9, a value of 0.615 is obtained. Thus, the level of influence exerted by the variable of Capital Adequacy Ratio (CAR), Financing to Deposit Ratio (FDR), Non Performing Financing (NPF), Operating Expenses and Operating Income (BOPO), and Good Corporate Governance (GCG) to Return On Asset (ROA) is 61.5\%. While the remaining 38.5\% is influenced by other variables not measured or examined in this study.

Table 8. Determination Coefficient Result

\begin{tabular}{ccccc}
\hline \multicolumn{4}{c}{ Model Summary $^{\mathrm{b}}$} \\
\hline Model & $\mathrm{R}$ & R Squere & Adjusted R Squere & Std. Error of the Estimate \\
\hline 1 &, $819^{\mathrm{a}}$ &, 671 &, 615 &, 96656 \\
\hline a. Predictors: (Constant), GCG, CAR, BOPO, FDR, NPF \\
\hline \multicolumn{3}{l}{ b. Dependent Variable: ROA }
\end{tabular}

Source : SPSS Output, 2017

\subsection{Discussion}

\subsubsection{CAR influence on ROA}

The test results of Capital Adequacy Ratio (CAR) on Return On Assets (ROA) show the regression coefficient value of Capital Adequacy Ratio (CAR) of 0.067 with a significance value of 0.002 . Because the significant value is less than 0.05 , it means that there is a significant influence of Capital Adequacy Ratio (CAR) on Return On Assets (ROA) partially. A positive regression coefficient variable indicates that Capital Adequacy Ratio (CAR) has a positive effect on Return On Assets (ROA). Thus, the amount of Capital Adequacy Ratio (CAR) value can affect the amount of Return On Assets (ROA) value of Islamic Banking.

The positive effect of Capital Adequacy Ratio (CAR) on Return On Assets (ROA) due to the increase of profitability followed by a decline in the need of reserves establishment in order to anticipate the consequences of increasing risk in line with the optimization of assets productivity, so that the capital adequacy of Islamic Banks as proxy for Capital Adequacy ratio (CAR) increases. The results of the study are consistent with research conducted by (Adyani, 2011; Fahmy, 2014; Prastiyaningtyas, 2010; Rahmi \& Anggraini, 2013; Wibowo \& Syaichu, 2013; Zulifiah \& Susilowibowo, 2014).

\subsection{2. $\quad$ FDR influence on ROA}

The test results of Financing to Deposit Ratio (FDR) on Return On Assets (ROA) show regression coefficient value of Financing to Deposit Ratio (FDR) of -0.045 with a significance value of 0.000 . This shows that Financing to Deposit Ratio (FDR) has an influence on Return On Assets (ROA) in Islamic banking with a negative coefficient. That is, if the Islamic bank wants to increase ROA then the bank must decrease the level of Financing to Deposit Ratio (FDR). The results of this research found that liquidity as a proxy for financing to Deposit ratio (FDR) shows how much money the bank releases for financing with negative direction toward profitability. The higher this ratio indicates more illiquid banks, which in turn causes a decrease in profitability. If the condition of banks is increasingly illiquid, the greater the liquidity risk will be borne by the bank. The risk in question is the unavailability of assets to meet the obligations to depositors. The results are 
consistent with research conducted by (Fahmy, 2014; Hakiim \& Rafsanjani, 2016; Muiawati, 2015) in Islamic Banks in Indonesia.

\subsubsection{NPF influence on ROA}

The results of partial test between the Non Performing Financing (NPF) on Return On Assets (ROA) indicate the value of regression coefficient of Non Performing Financing (NPF) of -0.413 with significant value of 0.002 . Judging from the significant value that is less than 0.05 , there is significant influence between the variables of Non Performing Financing (NPF) on Return On Asset (ROA) partially. The ratio of Non Performing Financing (NPF) reflects the credit risk faced by Islamic Commercial Bank. The higher the ratio, the worse the credit quality of banks due to the greater number of bad credit, so that the possibility of bank being in problematic condition is higher and it affects the decline in revenue due to an increase in the cost of productive reserves (Almilia \& Herdinigtyas, 2005; Pratiwi, 2012) Therefore, it can be concluded that the ratio of Non Performing Financing (NPF) negatively affects return on assets (ROA). These results are consistent with research conducted by (Adyani, 2011; Fahmy, 2014; Nugroho, 2006; Prastiyaningtyas, 2010; Pratiwi, 2012; Siti Nurkhosidah, 2009; Sulistianingrum, 2013).

\subsubsection{BOPO influence on ROA}

The test results obtained empirical evidence that the hypothesis $\mathrm{H}_{4}$ is rejected. The regression coefficient of Operating Expenses and Operating Income (BOPO) is 4,672E-0005 with significant value of 0.907 which is higher than 0.05 . This suggests that Operating Expenses and Operating Income (BOPO) has no effect on Return On Assets (ROA). That is, the level of Operating Expenses and Operating Income (BOPO) has no effect on the increasing profitability. The results of the study are consistent with studies conducted by previous researchers such as (Alifah, 2014). In her research, (Alifah, 2014) concluded that the Operating Expenses and Operating Income (BOPO) has no effect on Return On Assets (ROA) in Banking.

\subsubsection{GCG influence on ROA}

The test results obtained empirical evidence that the hypothesis $\mathrm{H}_{5}$ is rejected. It shows that good corporate governance (GCG) has no effect on Return On Assets (ROA). That is, the level of good corporate management did not ensure the increase in profitability of Islamic banking. Return on Assets (ROA) is a ratio that is used by banks to measure the ability of the bank management in gaining profit through assets held. The assets owned by banking company in this case is the asset collected from public funds. People tend to believe the banking company to entrust their funds because of the existence of the banking company itself in the society not because the people have traced the banking enterprise management performance. The results of this study are consistent with research conducted by (Prasinta, 2012). In her research, (Prasinta, 2012)concludes that Good Corporate Governance (GCG) has no effect on profitability as measured by return on assets (ROA).

\section{Conclusions}

The results shows that:

- Capital adequacy as measured by Capital Adequacy Ratio (CAR) has positive effect on 
return on assets of Islamic banking due to the increase of profitability followed by a decline in the need of reserves establishment in order to anticipate the consequences of increased risk in line with the optimization of assets productivity, so that the capital adequacy of Islamic Banks as proxy for with Capital Adequacy Ratio (CAR) increases. This shows that Islamic banks have been quite successful in utilizing the other additional sources of capital so that the capital growth can keep pace with its productive assets growth.

- Islamic banking liquidity level as measured by Financing to Deposit Ratio (FDR) significantly affects return on assets (ROA) of Islamic banking with negative coefficient. This means that banks need to lower the value of Financing to Deposit Ratio (FDR) if the banks want to increase Return On Assets by using cash reserves. The higher this ratio, the more illiquid the bank and this will reduce profitability.

- Asset quality measured by Non Performing Financing (NPF) negatively affects return on assets (ROA) of Islamic banking. This can be caused by the credit quality of banks getting worse due to the greater number of bad credits, so that the possibility of bank being in problematic condition is greater and it affects the decline in revenue due to an increase in the cost of productive reserves.

- Operational efficiency as measured by Operating Expenses and Operating Income (BOPO) has no effect on Return On Assets (ROA) of Islamic banking. This is evidenced by the positive value of beta by 4,672E-0005 with a significant value of 0.907 . The statistical t test results for beta variable has significant values of 0.907 higher than the fault tolerance of 0.05 , so the level of Operating Expenses and Operating Income (BOPO) in Islamic banking has no effect on the increase of profitability. This is due to the higher costs incurred by the bank in conducting its operations.

- Corporate governance as measured by GCG has no effect on ROA in Islamic banking because the assets held by the banking company come from public funds. The people tend to not pay attention to the performance of banks but see the bank existence in society to entrust their funds in Islamic banking companies.

\section{Limitation}

This study used only 7 samples from 12 Islamic Banks operating in Indonesia until the end of 2015. The six samples are Bank of Muamalat Indonesia, Bank of Syariah Mandiri, Bank of Mega Syariah, Bank of Panin Syariah, Bank Rakyat Indonesia Syariah, Bank Syariah Bukopin and Bank of Victoria Syariah. It also only used 5 years observation from 2011 to 2015. The variables used are limited to the main and supporting ratio of Islamic Banks in accordance with PBI No. 9/1/PBI/2007 concerning the Rating System for Commercial Banks based on Sharia Principles.

For further research, it is expected to increase the number of samples, not just limited to 7 Islamic Banks but expand the population by incorporating Islamic Rural Bank so that the results can be generalized and have different results. Then, for further research it is recommended to extend the period of study, not just 5 years. In addition to expanding populations and periods of study, further research is expected to add variables from the main and supporting ratio that have influence on Return On Assets. 


\section{Suggestions for the Future Studies}

Based on these results, the researchers tried to give some good advice to the researchers, the banks and the customers:

1. For further research, it is expected to increase the number of samples, not just limited to 7 Islamic Banks but to expand the population by incorporating Islamic Business Unit and Islamic Rural Bank so that the results can be generalized and have different results. Then, for further research, it is recommended to extend the period of study, not just 5 years. In addition to expanding populations and periods of study, further research is expected to add variable of main and supporting ratio that have an impact on Return On Assets.

2. For the banks to keep the ratio of Non Performing Financing (NPF) under BI terms of maximum of 5\% as well as to increase the efficiency of financing and to keep the FDR ratio at a safe level set by Bank of Indonesia.

3. For customers and investors, as a reference for the development of knowledge and insight about Islamic banks particularly about profitability that can be used as information for consideration in making investment decisions in Islamic Banking companies.

\section{References}

[1] Adyani, L. R. (2011). Analisis Faktor-Faktor yang Mempengaruhi Profitabilitas (ROA) (Pada Bank Umum Syariah yang terdaftar di BEI periode Desember 2005 - September 2010). Universitas Diponegoro. Retrieved from http://eprints.undip.ac.id/28747/1/Skripsi11.pdf

[2] Alifah, Y. B. (2014). Pengaruh CAR, NPL, BOPO, DAN LDR, Terhadap Profitabilitas Bank (ROA), Pada Perusahaan Perbankan Yang Terdaftar Di Bursa Efek Indonesia Periode 2009-2012. Univeristas Negeri Yogyakarta. Retrieved from https://eprints.uny.ac.id/17244/

[3] Almilia, L. S., \& Herdinigtyas, W. (2005). Analisis Rasio Camel Terhadap Prediksi Kondisi Bermasalah Pada Lembaga Perbankan Perioda 2000-2002. Jurnal Akuntansi Dan Keuangan, 7(2), 131-147. Retrieved from http://puslit2.petra.ac.id/ejournal/index.php/aku/article/view/16448

[4] Damastuti, I. E. (2010). Analisis Perbandingan Kinerja Keuangan Bank Syariah Dengan Menggunakan Income Statement Approach Dan Value Added Approach (Studi Kasus Bank Muamalat Indonesia Cabang Semarang). UNIVERSITAS DIPONEGORO. Retrieved from http://eprints.undip.ac.id/22982/1/SKRIPSI.pdf

[5] Danupranata, G. (2013). Buku Ajar: Manajemen Perbankan Syariah. Jakarta: Salemba Empat.

[6] Fahmy, M. S. (2014). PENGARUH CAR, NPF, BOPO DAN FDR TERHADAP PROFITABILITAS BANK UMUM SYARIAH. UIN Sunan Kalijaga Yogaykarta. Retrieved from http://digilib.uin-suka.ac.id/9885/

[7] Fitriyana, A. (2011). Pengaruh Rasio Kecukupan Modal, Likuiditas, Non Performing Loans, Equity To Asset Ratio Dan Time Deposite Ratio Terhadap Return On Asset Bank. Unvieritas Diponegoro.

[8] Hakiim, N., \& Rafsanjani, H. (2016). Pengaruh Internal Capital Adequency Ratio (CAR), Financing To Deposit Ratio (FDR), dan Biaya Operasional Per Pendapatan Operasional (BOPO) dalam Peningkatan Profitabilitas Industri Bank Syariah di 
Indonesia. Jurnal Aplikasi Manajemen, 14(1), 161-168. https://doi.org/10.18202/jam23026332.14.1.17

[9] Iska, S. (2012). Sistem Perbankan Syariah di Indonesia Dalam Perspektif Fikih Ekonomi. Yogyakarta: Fajar Media Press.

[10] Janah, N., \& Siregar, P. A. (2018). PENGARUH RASIO KEUANGAN TERHADAP PROFITABILITAS PERBANKAN SYARIAH INDONESIA. At-Tawassuth, 3(1), 621-641.

[11] Kieso, D. E., Weygandt, J. J., \& Warfield, T. D. (2008). Intermediate Accounting. Jakarta: Erlangga.

[12] Muiawati, S. (2015). Faktor-Faktor Penentu Profitabilitas Bank Syariah Di Indonesia Skripsi. UNIVERSITAS NEGERI SEMARANG. Retrieved from https://lib.unnes.ac.id/21989/1/7311411047-s.pdf

[13] Nugroho, A. W. (2006). ANALISIS PENGARUH FDR, NPF, BOPO, KAP DAN PLO TERHADAP RETURN ON ASSET Aluisius Wishnu Nugroho. Universitas Diponegoro. Retrieved from https://core.ac.uk/download/pdf/11735524.pdf

[14] Prasinta, D. (2012). Pengaruh Good Corporate Governance Terhadap Kinerja Keuangan. Accounting Analysis Journal, 2(2), 1-14. https://doi.org/10.1007/s10048014-0430-0 LK

http://rug.on.worldcat.org/atoztitles/link/?sid=EMBASE\&issn=13646753\&id=doi:10.1 007\%2Fs10048-014-0430-

$0 \&$ atitle $=$ Transcriptome + analysis + of + grey + and + white + matter + cortical + tissue + in + mul tiple + system + atrophy\&stitle $=$ Neurogenetics \& title $=$ Neurogenetics \&volume $=16 \&$ issue $=2 \&$ spage $=107 \&$ epage $=122$ \&aulast $=$ Mills\&aufirst $=$ James + D.\&auinit $=$ J.D.\&aufull $=$ Mi lls + J.D.\&coden $=$ NEROF \&isbn $=\&$ pages $=107-122 \&$ date $=2015 \&$ auinit $1=$ J\&auinitm $=$ D.

[15] Prastiyaningtyas, F. (2010). FAKTOR-FAKTOR YANG MEMPENGARUHIPROFITABILITAS PERBANKAN(Studi pada Bank Umum Go Public Yang Listed di Bursa EfekIndonesia Tahun 2005-2008). Universitas Diponegoro. Retrieved from http://eprints.undip.ac.id/22950/

[16] Pratiwi, D. D. (2012). Pengaruh CAR, BOPO, NPF DAN FDR Terhadap Return On Asset (ROA) Bank Umum Syariah (Studi Kasus pada Bank Umum Syariah di Indonesia Tahun 2005 -2010). Universitas Diponegoro Semarang. Retrieved from http://eprints.undip.ac.id/35651/1/Skripsi_PRATIWI.pdf

[17] Rahmi, N., \& Anggraini, R. (2013). Pengaruh CAR, BOPO, NPF, DAN CSR DISCLOSURE Terhadap Profitabilitas Perbankan Syariah. Jurnal Ilmiah Wahana $\begin{array}{llll}\text { Akuntansi, } & \text { 8(2), } & \text { Retrieved } & \text { from }\end{array}$ http://journal.unj.ac.id/unj/index.php/wahana-akuntansi/article/view/861

[18] Siti Nurkhosidah. (2009). Analisis Pengaruh Variabel NPF,PPAP, FDR,BOPO Terhadap Profitabilitas Pada Bank Syariah Mandiri. Skrispsi. UNIVERSITAS ISLAM NEGERI SUNAN KALIJAGA.

[19] Sulistianingrum, D. R. (2013). ANALISIS PENGARUH FINANCING TO DEPOSIT RATIO (FDR), DANA PIHAK KETIGA (DPK), SERTIFIKAT BANK INDONESIA SYARIAH (SBIS), DAN NON PERFORMING FINANCING (NPF) TERHADAP RETURN ON ASSET (ROA), PERIODE JANUARI 2009 - DESEMBER 2012. UNIVERSITAS ISLAM NEGERI SYARIF HIDAYATULLAH JAKARTA.

[20] Wibowo, E. S., \& Syaichu, M. (2013). ANALISIS PENGARUH SUKU BUNGA, INFLASI, CAR, BOPO, NPF TERHADAP PROFITABILITAS BANK SYARIAH. Diponegoro Journal of Management, 2(2), 10-19. Retrieved from https://ejournal3.undip.ac.id/index.php/djom/article/view/2651 
[21] Yuliani, Y. (2007). Hubungan Efisiensi Operasional Dengan Kinerja Profitabilitas Pada Sektor Perbankan Yang Go Publik Di Bur .... Jurnal Manajemen \& Bisnis Sriwijaya, $5(10), 12-41$.

[22] Zulifiah, F., \& Susilowibowo, J. (2014). PENGARUH INFLASI, BI RATE, CAPITAL ADEQUACY RATIO (CAR), NON PERFORMING FINANCE (NPF), BIAYA OPERASIONAL DAN PENDAPATAN OPERASIONAL (BOPO) TERHADAP PROFITABILITAS BANK UMUM SYARIAH PERIODE 2008-2012. Jurnal Ilmu Manajemen, 2(3), 759-770. 